\title{
FLORISTIC STUDY OF FAMILY SOLANACEAE OF AMGAON REGION, GONDIA DISTRICT (M.S.)
}

\author{
Nakade J. G. *, Awaley M. G., Patale C. K. \\ P.G. Department of Botany, Bhawabhuti Mahavidhyalaya, Amgaon Dist Gondia \\ 441902 (M.S.) India. \\ Email: jayendranakade26@gmail.com
}

\begin{abstract}
:
The investigation was carried out in order to explore the existing floristic composition in Amgaon, Dist Gondia (Maharashtra). The present area of Amgaon was selected for the floristic studies because it has been given little attention of its vegetation. A Total of 13 species under 08 genera of solanaceae were collected. Among 08 genus Solanum is mostly dominant. A complete account of each species is given with correct nomenclature, local name, flowering \&fruiting season and their Medicinal and Economical important. Is enumerated in results.
\end{abstract}

Key words: - Solanaceae, Floristic study.

\section{INTRODUCTION:}

The Solanaceae or nightshades are an economically and medicinally important family of flowering plants. The Solanaceae consists of about 98 genera and some 2,700 species, with a great diversity of habitats, morphology and ecology. The family ranges from annual and perennial herbs to vines, lianas, epiphytes, shrubs and trees, and includes a number of important agricultural crops, medicinal plants, spices, weeds, and ornamentals. Many members of the family contain potent alkaloids, and some are highly toxic, but many cultures eat nightshades, in some cases as staple foods. The family belongs to the order Solanales, in the asterid group Dicotyledones (Magnoliopsida).

The name Solanaceae derives from the genus solanum, "the nightshade plant". The etymology of the Latin word is unclear. The name may come from a perceived resemblance of certain solanaceous flowers to the solanum is known as the "sunberr". Alternatively, the name could originate from the Latin verb solari, meaning "to soothe", presumably referring to the soothing pharmacological properties of some of the psychoactive species of the family.

Members of the Solanaceae family are found throughout the world but are most abundant and widely distributed in the tropical regions of Latin America, where about 40 genera are endemic. Very few members are found in temperate regions, and only about 50 species are found in the united states and Canada combined. The genus solanum contains almost half of all the species in the family, including all the species in the family, including all the species of wild potatoes found in the western hemisphere. The poisonous alkaloids present in some species of the family have given the latter its sonbre vernacular name of "nightshade".

The family is also informally knows as the nightshade or potato family. The family includes Datura, Mandragora, Belladonna, Capsicum, Solanum, etc. 
The Solanaceae family is characteristically ethno- botanical that is, extensively used by humans. It is important source of food, spice and medicine. However, Solanaceae species are rich in alkaloid whose toxicity to humans and animals ranges from mildly irritating to fatal in small quantities.

Solanaceae because of the high diversity and beneficial properties to human beings extensively remain the subject of taxonomical studies in history.

From the early years of the twenty centuries taxonomist from different regains paid attention to this family. Kirk (1927) studied the Solanaceae of Britain. In this area Solanaceae was represented by twelve different genera. According to Kirk Solanum and Datura genus has narcotics properties. Solanum nigram L. is an invasive species whereas in the past it was cultivated in this regain for its medicinal properties.

Members of the Solanaceae family are annuals, biennials, or perennials and are usually herbs, though some species grow as shrubs or small trees. The leaves are generally simple and alternately arranged, often lobed, of hairy, sometimes with prickles. The regular flowers are mostly pentamerous. The petals from a corolla tube, at least at the base. There are 5 stamens, alternating with the corolla lobes. The ovary is of 2 cells, sometimes 4, with many ovules on axile placentas ( see placentaion), and a terminal style. The fruits may be capsule or berries.

\section{Solanaceae are}

known for possessing a diverse range of alkaloids. One of the most important groups of this compound is called the tropane alkaloids.

Chemically, the molecules of these compound have a characteristic bicyclic structure and include Scopolamine, Atropine \& hyoscyamine. These are the key alkaloids of this family. Presence of these alkaloids makes this family medicinally important.
Pharmacologically, these are the most powerful known anticholinergics in existence, meaning they inhibit the neurological signals transmitted by the endogenous neurotransmitter, acetylcholine. Symptoms of overdose may include mouth dryness, dilated pupils, ataxia, urinary retention, hallucinations, convulsions, coma and death.

Despite the extreme toxicity of the tropanes, they are important durge when administered in appropriate dosages. They can reverse the cholinergic poisoning, which can be caused by overexposure to pesticides and chemical warfare agents such as sarin. More commonly, they can halt many types of allergic reactions. Scopolamine, a commonly used ophthalmological agent, dilates the pupils and thus facilitates examination of the interior of the eye. They can also be used as antiemetic in people prone to motion sickness or receiving chemotherapy.

Medicinally important species of the family Solanaceae belong to following genera namely:

- Solanum

- Atropa

- Capsicum

- Datura

- Withania

- Hyoscymus

- Nicotina

Moreover, the Solanaceous taxa from Amgaon Tahsil of Gondia Distric.(M.S.) have not been investigated. In view of all these facts, a comprehensive study dealing with Floristic study and taxonomy is undertaken with the following objective:

1. To update the current diversity status of Solanaceae taxa in Amgaon;

2. To find out total number of species and genus of Solanaceae family in Amgaon

3. To study distrubutation pattern of Solanaceae taxa in Amgaon tahsil 
4. To find out wild,cultivated and ornamental plant of Solanaceae family.

5. To study economical and Medicinal uses of Solanaceae family

\section{PREVIOUS WORK}

The family belongs to the order Solanales,in the asteroids group dicotyledons. The Solanaceae consist of about 98 genera and 2700 species with a great diversity of habitat.

Many floristic works have been published by botanist woking in different institute. the important are "flora of Osmanabad" (Nike 1968), "Flora of Marathwada" (Nike 1998), "Flora of Amaravati District (Dhore 2002)

"Flora of Kolhapur District" (yadav and Sardesai 2002); studied the vegetation of Kolhapur District and reported 12 genus and 38 species of solanaceae. "Flora of Akola District" (kambale and pradhan1998), "Flora of yavatmal" (Kartikeyen and Anandkumar,1993).

Flora of Baramati (Bhagat,Simpale And Deshmukh 2008), Studied the vegetation of Baramati District and reported 08 genus and 18 species of solanaceae

Floristic Survey of Different areas of Maharashtra have been complied published by Botanical Survey of India. Flora of Maharashtra state Monocotyledon" Sharma et al,1996 "Flora of Maharashtra state, Dicotyledones" Singh et al., (Vol.1,2000,Vol. II,2001)

Kahalkar (2009), Studied the vegetation of Gondia District and reported 13 species of Solanaceae

Yadav R.Rathi M and A.Penekar (2015) Studied A detailed review on Solanaceae a

Shah et al (2013),studied medicinal plants from Solanaceae family

Ulhe and Kale (2016) Studied structural variation of seed in some species of Cucurbitaceae and Solanaceae.

\section{Study area (Amgaon Tahsil)}

Amgaon Tahsil (20039'0"N 79057'O”E) is one of the eight Tahsil of Gondia District which is situated East of Gondia district. Adjoining district of Amgaon on North side Balaghat district of Madhya Pradesh and on Eastern side is Salekasa Tahsil of Gondia district. To the West side is Gondia and Goregaon Tahsil of Gondia District. To the South side is Deori Tahsil of Gondia District. (Map 1 and 2)The Tahsil covers an area of 32112.21 sq. hectors of which 6266.144 sq. hectors fall under forest area. Out of the total forest area 597.100 sq. hectors under reserve forest area; 2718.594 sq. hectors under protected forest area and 2520.860 sq. hectors under zudpi jungle. Remaining forest area i.e. 127.592 sq. hectors fall under miscellaneous forest. Bagh River is the most important river.

The whole area of the district is rolling and opens at the average elevation of $320 \mathrm{~m}$ above sea level. There are no major dams are present in the Amgaon. Apart from this, more than 80 small tanks are present in the Amgaon Tahsil. These tanks are the vital source of irrigation of the Tahsil. The climate of the Tahsil is similar as district with a few variations. The average rain fall till $26^{\text {th }}$ September 2016 is $1734.5 \mathrm{~mm}$ which at Lowerside than district average $(+1988.39 \mathrm{~mm})$.

\section{MATERIAL AND METHODS:-}

District Gondia (20.390 and $21.38^{\circ}$ North latitude and 79.2270 to $82.42^{\circ}$ East longitudes)

Frequent field visit were conducted during 2017 to 2019 to various localities of Amgaon Tahsil and 13 specimens of family Solanaceae were collected from different localities of the Amgaon Tahsil. Some of localities visited twice during the different season of the year.

All the vouchers have been made in triplicate. Relevant field notes were made on the spot in the field book and field number was given to each specimen. Plant specimens were identified with the help of published state, regional and district floras. Some of the specimen that found difficult to identify were confirmed by matching 
them with authentically identified species deposited in the herbarium, Department of Botany, Bhawabhuti Mahavidyalaya Amgaon.

\section{RESULTS AND DISCUSSION}

Capsicum annuum L. Sp. Pl. 188. 17753; Cooke, Fl. Pres. Bombay 2:347.1958(Repr.); Deb in J.Econ. Tax. Bot. 1:35.1980. (Fig-1)

Var.annuum. 'Mirchi'.

Herbs, erect. Leaves 3.5-6.0 x 1.5-2.0 $\mathrm{cm}$, ovate -lanceolate. Flowers solitary, white. Berries 8.5 × $0.8 \mathrm{~cm}$, red when ripe. Seeds orbicular, flat.

Distrib.: A native of tropical America. Cultivated for its edible berries.

F1s.\& Frts. :- July-August.

Locality :- Anjora

Exsiccata :-BMV-1728

Cestrum nocturnum L. Sp. Pl. 191. 1753; Bailey, Man. Cult. P1. ed. 2, 874.1949. (Fig-2)

Shrubs, erect, much branched, $2-4 \mathrm{~m}$ tall; branchlets angled. Leaves $8-15 \times 3 \mathrm{~cm}$, oblong-ovate to elliptic, acuminate at apex. Flowers in axillary or terminal, cymose panicles, sweet-scented. Berries ovoid. Seed numerous, compressed.

Distrib. : Native of West Indies, planted in garden.

Fls. \& Frts. :- November - February.

Locality :- Pangaon.

Exsiccata :- BMV -1724

Datura metal L.Sp. 179. 1753; Sant in J. Bombay Nat. Hist. Soc. 47:657. 1948; Avery et al. in Blakeslee, Genus Datura 32, f. 1959; Deb in J. Econ. Tax. Bot. 1:37. 1980. D.fastuosa L. Syst. Nat. ed. 10, 2:932. 1759; C.B.Cl. in Hook. F. Fl. Brit. India 4: 243. 1883; Cooke, F1. Pres. Bombay 2:343. 1958 (Repr.). D. Fastuosa var. alba C.B.Cl. in Hook. f. op. cit. ; Cooke, op. cit. 344. 'Kala-Dhotra'. (Fig-3)
Herbs, erect, glabrous or subglabrous; stems often muricate and tinged with purple. Leaves $10-15 \times 8-13 \mathrm{~cm}$, broadly ovate triangular, shallowly lobed. Flowers purple, axillary, solitary. Capsules $2.0-3.5 \mathrm{~cm}$ across, drooping, globose, nodding on curved pedicels. Seeds numerous, yellowish -brown.

Distrib. : Frequent in waste lands.

Fls. \& Frts. :- September-December.

Locality :- Anjora

Exsiccata :- BMV -1730

Lycopersicon lycopercicum (L) Karstem. Deutsch. Fl. 966. 1855; Deb in J. Econ. Tax. Bot. 1: 4. 1980. Solanum lycopersicum L. Sp. Pl. 185. 1753. Lycopersicon esculentum Mill. Gard. Dict. ed. 8, no. 2.1768; C.B.Cl. in Hook. f. Brit. India 4:237. 1883; Cooke, Fl. Pres. Bombay 2: 345. 1958 (Repr.). 'Tamata'.( Fig-4)

Herbs, sticky, pubescent. Leaves pinnatisect. Flowers yellow, solitary, axillary. Berries irregularly 4 -6 -lobed, depressed globose. Seeds discoid.

Distrib. : Native of tropical America, fruits used as vegetable. Cultivated.

Fls. \& frts :- Throughout the year.

Locality :- Anjora.

Exsiccata :- BMV -1727

Petunia hybrid Vilm. F1. P1. Terr. 615, 1875; Naik, Fl. Mar. 2: 612, 1998; Singh etal, Fl. Ms. 2: 515, 2000. (Fig.5)

Herbs, erect, glandularpubescent, $40-50 \mathrm{~cm}$ tall; stem fistular. Leaves elliptic-lanceolate, $3-6 \times 1.5-3 \mathrm{~cm}$, cuneate at base, subacute, glabrescent, the lower ones narrowed into a distinct petiole, the upper ones sessile, gradually smaller, passing into bracts. Flowers variously coloured, 5-7 cm long; pedicels $2-5 \mathrm{~cm}$ long, glandular hairy. Calyx 1$1.5 \mathrm{~cm}$ long, glandular hairy outside; sepals lanceolate, obtuse. Corolla glandular-hairy 
outside; lobes rounded, obtuse. Stamens 5; 4 in pair the fifth rudimentary. Capsules ovoid, 2valved. Seeds numerous, small

Fls. \& Frts. :- June - October

Locality :- Amgaon

Exsiccata :- BMV-1731

Physalis minima L., Sp. Pl. 183. 1753; C. B. Cl. in Hook. f. Fl. Brit. India. 4: 238. 1883; Cooke, Fl. Pres. Bombay 2: 340. 1958 (Repr.); Sant. in J. Bambay nat Hist. Soc. 47: 657. 1948; Deb in J. Ecom. Tax. Bot. 1:43. 1980. 'Chirboti', 'Ran popati'.( Fig-6)

Herbs c $30 \mathrm{~cm}$ high, annual, erect. Leaves $2.0-6.5 \times 1.5-5.0 \mathrm{~cm}$, ovate, elliptic or elliptic -oblong. Flowersaxillary,solitary.Berries $1.2-2.5 \mathrm{~cm}$ long, ovoid or subglobose. Seeds numerous, orange-yellow.

Distrib. : Common throughout in open situations.

Fls.\& Frts :- July - April.

Location:- Anjora.

Exsiccata:- BMV -1721.

Solanum denticulatum Bl. Bijdr. 697. 1825; C.B.Cl. in Hook. f. Fl. Brit. India 4: 231 1883; Cooke, Fl. Pres. Bombay 2: 334. 1958 (Repr.). ( Fig-7)

Shrubs, $1.0-1.5 \mathrm{~m}$ high. Lower leaves solitary, upper in unequal pairs, $5-12 \times 2.5-$ $5.5 \mathrm{~cm}$, elliptic -lanceolate, sparsely hairs above, glabrous beneath. Flowers in lateral fascicles. Berries globose, c $1 \mathrm{~cm}$ across, red when ripe.

Distrib. : Infrequent along the ghats.

Fls. \& Frts :- October -November.

Locality :- Anjora.

Exsiccata :-BMV - 1722.

Solanum melongena L. Sp. Pl. 186. 1753; C.B.Cl. in Hook. f. Fl. Brit. Indies 4: 235. 1883;
Cooke, Fl. Pres. Bombay 2: 339. 1958 (Repr.);

Deb in J. Econ. Tax. Bot. 1: 48. 1980.( Fig-8)

Var. melongena. 'Vangi'.

Shrubs, gery stellate -tomentose.

Leaves 3-10 × 3-7 cm, ovate or ovate -oblong, pinnatified, stellate -pubescent. Flowers $1.0-1.5$ $\mathrm{cm}$ long, violet, in short, extra axillary racemes.

Distrib. : Native of East Indies. Widely cultivated for its fruits, used as vegetables.

Fls. \& Frts. :- Throughout the year.

Locality :- Anjora.

Exsiccata :- BMV - 1729.

Solanum nigrum L. Sp. Pl. 186. 1753; C.B.Cl. in Hook. f. Fl. Brit. India. 4: 229.1883; Cooke, Fl. Pres. Bombay 2: 233. 1958 (Repr.); Sant in J. Bombay nat. Hist. Soc. 47: 652. 1948; Deb in J. Econ. Tax. Bot. 1: 49. 1980. 'Kangani. ( Fig-9)

Herbs c $30 \mathrm{~cm}$ high. Leaves $2.0-2.5$ x 1 $\mathrm{cm}$, broadly ovate or ovate -lanceolate, membranous, apex acute. Inflorescence of subumbellate cymes. Flowers white, pendulous. Berries globose, purplish -black when ripe. Seeds discoid, minutely pitted, yellow.

Distrib. : Common throughout as a weed in open situations.

Fls. \& Frts. :- May-June.

Locality :- Amgaon.

Exsiccata :- BMV -1732

Solanum torvum SW. Prodr. 47. 1788; C.B.Cl. in Hook. f. Fl. Brit. India 4: 234 1883; Bhogaonkar \& Devarkar, Add. Fl. Melghat 41, figs. A -G. 1999. (Fig-10)

Shrubs, 2.5 -3.6 m high, densely covered with stellate hairs; stem and petioles prickly. Leaves 15.5 x $10.0 \mathrm{~cm}$, ovate, shallowly lobed, shortly acuminate at apex, subcordate at base. Flowers white, $1.5-2.0 \mathrm{~cm}$ across, many in dense cymes. Berries globose, shining yellow when ripe. Seeds brown. 
Distrib. : Rare. Occasionally around villages.

Fls. \& Frts :- September -January.

Locality :- Amgaon.

Exsiccata :- BMV -1725.

Solanum tubersosum L. Sp. Pl. 185. 1753;

C.B.Cl. in Hook. f. Fl. Brit. India 4: 229. 1883;

Bailey, Man. Cult. Pl. ed. 2,868. 1949; Cooke, F1. Pres. Bombay 2: 339. 1958 (Repr.). 'Batata'।

\section{Fig-11)}

Herbs, $30-75 \mathrm{~cm}$ high, erect. Leaves compound; leaflets $3-4$ pairs, ovate or elliptic. Flowers white to bluish, few in long -penduncled forking clusters.

Distrib. : Introduced from America. Mostly cultivated for edible tubers, cooked as vegetable.

Fls. \& Frts. :- January -March.

Locality:- Anjora.

Exsiccata :- BMV -1726 .

Solanum virgnianum L. Sp. Pl. 187. 1753; Hepper \& Jacq. In Kew. Bull. 41: 433. 1986. S. surattense Burm. Fl. Ind. 57. 1768; sant in Bull. Bot. Surv. India 3: 20. 1961; Deb. in J E.com. Tax. Bot. 1: 51.1980. S. xanthacarpum Schrad. \& Wendl. Sert. Hanov. 1:8, t. 2. 1795; C.B.Cl. in Hook. f. Fl. Brit . India 4: 236. 1883; Cooke, Fl. Pres. Bombay 2: 335. 1958 (Repr.); Sant in J. Bombay nat. Hist. Soc. 47: 653. 1948. 'Bhui -ringni', 'Guiri', 'kate -ringni'. (Fig12)

Herbs, prostrate or decumbent -asending widely branched. Leaves $4.0-8.5 \times 2.5-5.5 \mathrm{~cm}$, ovate elliptic, stellately hairy on both sides, prickly on nerves. Inflorescence of extra axillary, few flowered cymes. Flowers purple. Berries yellow. Seed numerous.

Distrib: Common throughout in waste places on sandy river beds and fields as a weed.

Fls. \& Frts. :- December -May.

Locality :- Anjora.

Exsiccata :- BMV -1723
Withania somnifera (L.) Dunal in DC. Prodr. 13: 453. 1852; C.B.Cl. in Hook. f. Fl. Brit. India 4: 239. 1883; Cooke, Fl. Pres. Bombay 2: 341. 1958 (Repr.); Deb in J. Econ. Tax. Bot. 1: 52. 1980. Physalis somnifera L. Sp. Pl. 182. 1753.

(Fig-13)

Undershrubs, c $90 \mathrm{~cm}$ high, much branched. Leaves $5-10 \times 2.5-5.0 \mathrm{~cm}$, ovate, more or less minutely stellately pubescent, apex subacute, Flowers yellow. Berries globose, smooth, red when ripe. Seeds oblong or nearly spherical.

Distrib. : Frequent as a weed in waste places and roadsides.

Fls. \& frts. :- March -July.

Locality :- Amgaon Exsiccata :- BMV -1733

The detailed floristic account of solanaceae family of Amgaon Tahsil of Gondia District (M.S.) is outcome of more than fifteen extensive and intensive visit to various localities, including private areas and cultivated field, of Amgaon Tahsil carried out during 2016-17.The present work is based on the collection made during present work and herbarium vouchers housed in the herbarium, Department of Botany,Bhawabhuti Mahavidhyalaya,Amgaon.The total 13 species and 08 genera have been reported from Amgaon.

Kartikeyan and Anandkumar (1993) reported 7 species and 3 genera of solanaceae from yavatmal District.

Sing and Karthikeyan(2000) reported 57 species and 15genera of solanaceae from Maharashtra state which distributed throughout all over in Maharastra.It included all wild,ornomental as well as cultivated species.(Table-1 and Graph-1) yadav and Sardesai 2002, studied the vegetation of Kolhapur District and reported 12 genera and 38 species of solanaceae

Bhagat, Simpale And Deshmukh 2008, Studied the vegetation of Baramati District and reported 08 genera and 18 species of solanaceae 
Kahalkar(2009)reported 13 species and 08 genera of solanaceae from Gondia District. In which ornomentatal species were not included Comparative analysis of species range which was reported in different District and all over Maharashtra state, it is clearly seen that Family Solanaceae is widely Distributed throughout in Maharashtra state, Gondia District and Amgaon Tahsil.(Graph-2).

\section{Comparative account of species}

In present work Author included all wild, cultivated and ornamental species. Members of Solanaceae provide a variety of culinary, medicinal,and ormamental values.In term of culinary value,the most important species of this family is the potato or Solanum tuberosum, whose carbohydrate rich tubers have been a staple food in many time and places,and which is one of the most grown crops today.Also family consist many vegetable Genera such as Capsicum,Lycopersicon etc.(Table No-2)

Medicinally, members of Solanaceae have been prized for their alkaloid content. Important drug plants include Atropa belladonna, Datura stramonium, Hyoscyamus niger, Nicotiana tabacum.

As ornamental plants, the genera Petunia, Schizanthus, Browalli. Some plants also are focus of extensive biological study as model experiment, including the Petunia, Tobacco, tomato and Potato

\section{ACKNOWLEDGEMENT}

Authors are thankful to shri Sureshbabu Asati,President,B.S.S.,Shri

K.L.Mankar,Secretary B.S.S. and Principal S.M.Bhuskute for encouragement and providing facilities.

\section{REFERENCES}

Kirk, J. W. C. A British garden flora 1927
Bethum, G. \& J.D. Hooker. 1862-1883. Genera Plantarum. Vol. I-III, Wienheim Verlag Von J. Cramer.

Champion, H.G. 1936. A Preliminary Survey of the forest type of Indian and Burma. Ind. For. Rec. 1: 1-286.

Champion, H.G and S.K. Seth. 1968. A Revised Survey of Forest Types of India, Govt. of India, New Delhi.

Cooke, T. 1958. The Flora of the presidency of Bombay. Botanical Survey of India (Repr.ed.) Calcutta, Vols. I-III.

Diwakar, P. G. and B. D. Sharma 1999. Flora of Buldhana District, Maharashtra state. Botanical Survey of India, Calcutta.

Gamble, J. S. and C.E.C. Fischer. 1915-1936. Flora of the presidency of Madras. Botanical Survey of India, Calcutta.

Graham, R. J. D. 1911. List of wild plants found on the Nagpur and Telankheri farms. Govt. press, Nagpur.

Haines, H. H. 1912-1814. List of trees, shrubs and economic herbs of the southern forest circle of the Central Provinces. Ind. For. 38: 495-509. 1912; 39: 4969, 1913; 40: 194-229, 264-283, 330355, 392-403, 429-449, 472-502.

Haines, H. H. 1916. Descriptive list of trees, shrubs and economic herbs of the Southern circle, Central provinces. Allahabad.

Hooker, J. D. 1827-1897. The flor of British India. Vol. I-VII. London.

Kahalkar, V. I. 2009. Floristic Studies on Gondia District of Maharashtra State. Ph. D. Thesis, R.T.M. Nagpur University. 387-396.

Kamble, S.Y. 1988. Flora of Akola district, Maharashtra. Botanical Survey of India, Pune. 
Karthikeyan, S. \& Anandkumar. 1993. Flora of Yavatmal District, Maharashtra. B.S.I.FL. India ser. 3.

Maheshwari, J.K. 1960-1963. The Flora of Delhi, C.S.I.R. Delhi.

Maheshwari, J.K. 1966. Illustration to the Flora of Delhi. Delhi.

Matthew, K.M. 1983. The Flora of the Tamil Nadu Carnatic. The Rapinat herbarium St. Joseph's Collage. Tiruchirapalli.

Naik, V.N. 1979. The Flora of Osmanabad. Venus Publishers, Aurangabad.

Naik, V.N. 1977. Key to Angiospermic Families and Certain Genera of Marathwada, Aurangabad.

Naik, V.N. 1998. Flora of Marathwada, Vol. I \&II. Amrut Prakashan, Aurangabad.

Singh, N.P. and Karthikeyan, S. (eds.) 2000.

Flora of Maharashtra State. Dicotyledon - Vol. I, B.S.I. Calcutta.

Ugemuge, N.R. 1986. Flora of Nagpur District Maharashtra state. Shree Prakashan.

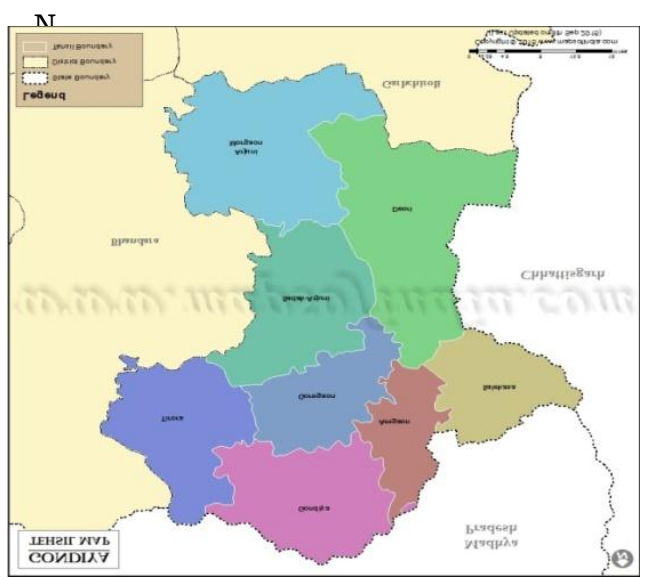

Map 1.Gondia Dist. agpur.

Shaha V.V.et al.2012,historical aspect of solanaceae.IJPRBS.

Watt, G. 1889-1899. A dictionary of Economic Products of India Vol. I-VI Calcutta.

Wright, R. 1840-1850. Illustration of Indian Botany. London.

Wright, R. 1840-1853. Icon Plantarum Indiae Orientalis, or figures of India Plants. 6 vol. Madras.

Yadav, S.R. and M.M. Sardesai, 2002. Flora of Kolhapur District. Shivaji University Publication, Kolhapur.
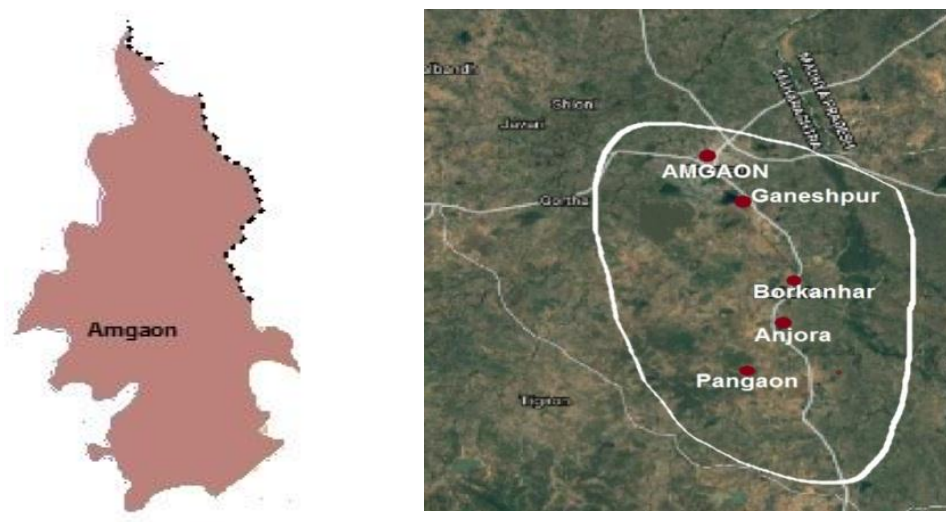

Amgaon 
Table-1

\begin{tabular}{|c|c|c|}
\hline & Genera & Species \\
\hline Maharashtra state & 15 & 57 \\
\hline Gondia District & 08 & 13 \\
\hline Amgaon Tahsi & 08 & 13 \\
\hline
\end{tabular}

Genera\& Species Family Solanaceae in M.H,Gondia District.\& Amgaon Tahsil

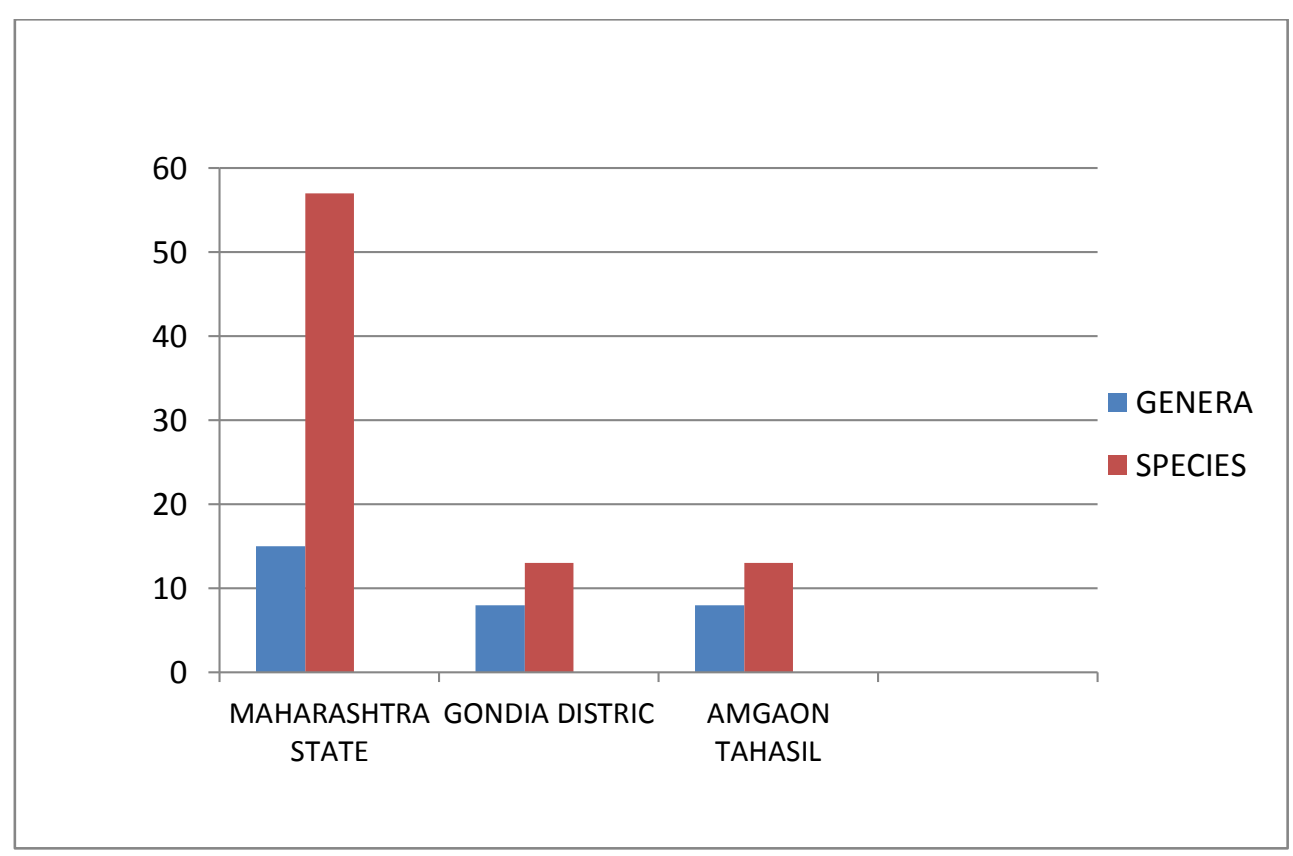

Comparative Account of genera (Graph_2)
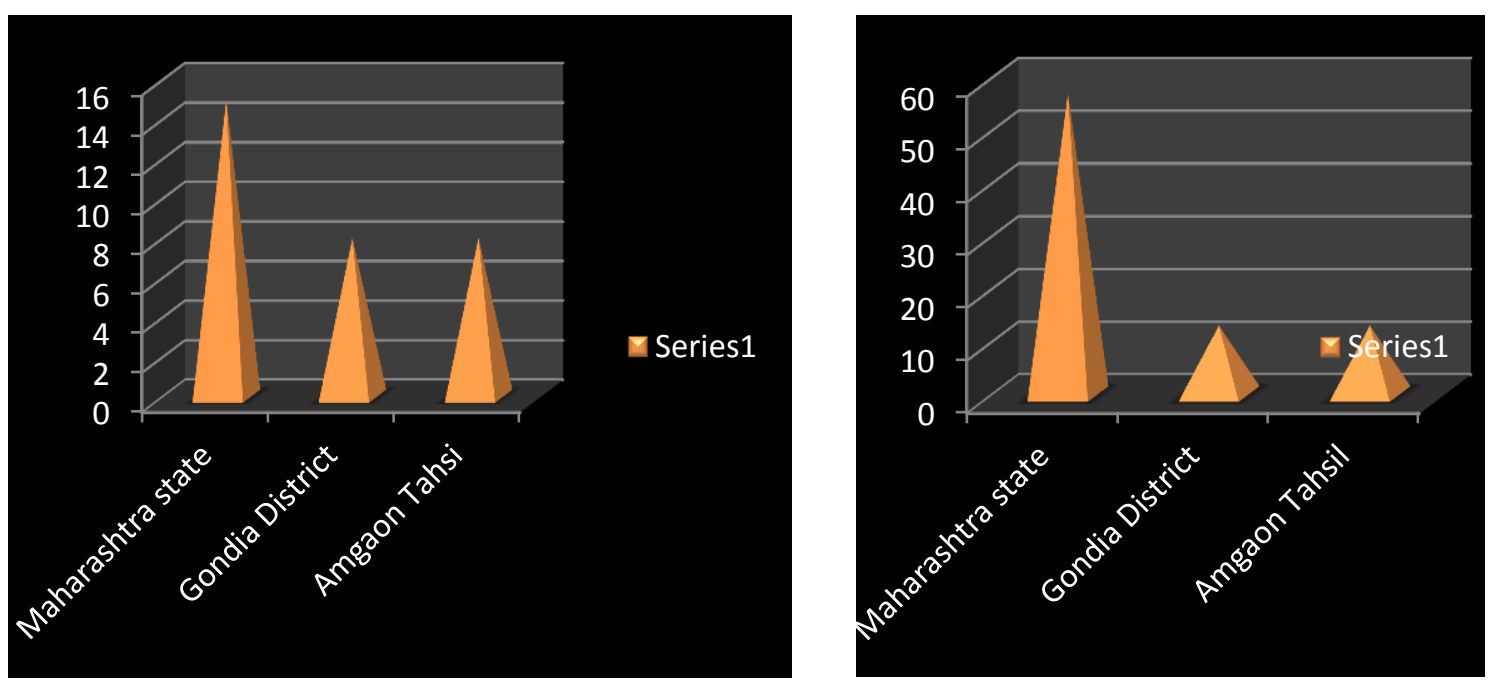
Comparative Account of Vegetable,Ornomental,and Medicinal plants species of Solanaceae (Table No 2)

\begin{tabular}{|l|l|l|}
\hline Solanaceae & Genera and species & Total no \\
\hline Vegetable plants & $\begin{array}{l}\text { Capsicum annum, Lycopersicon lycopercicum, Solanum } \\
\text { melongena, S.tuberosum }\end{array}$ & $\mathbf{0 4}$ \\
\hline Medicinal plants & $\begin{array}{l}\text { Cetrum nocturnum, } \\
\text { Datura metal, } \\
\text { Physalis minima, S.denticulatum, } \\
\text { S.nigrum, } \\
\text { S.taruum, } \\
\text { S.virgnianum, } \\
\text { Withania somnifera }\end{array}$ & $\mathbf{0 8}$ \\
\hline Ornamental plants & Petunia hybrid & $\mathbf{0 1}$ \\
\hline
\end{tabular}




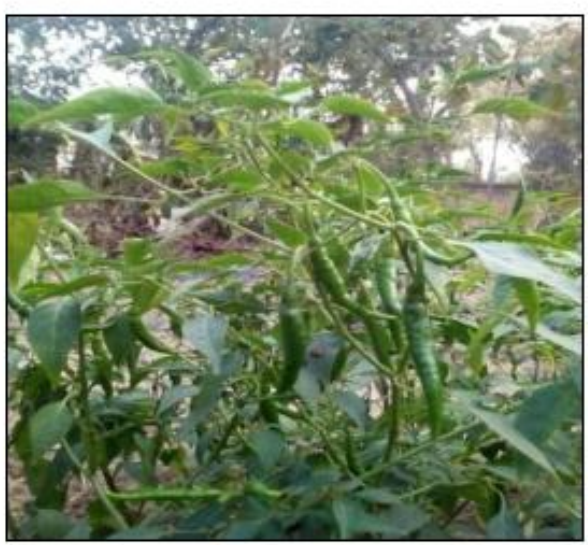

Fig. 1 Capsicum annum L.

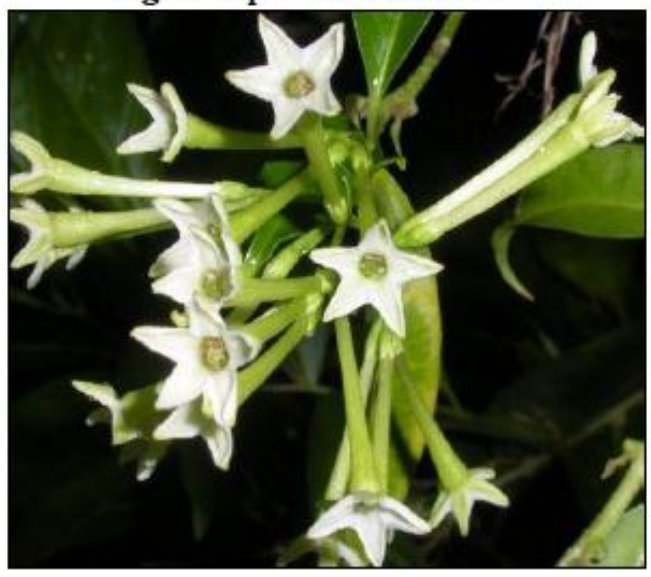

Fig. 2 Cestrum nocturnum L.

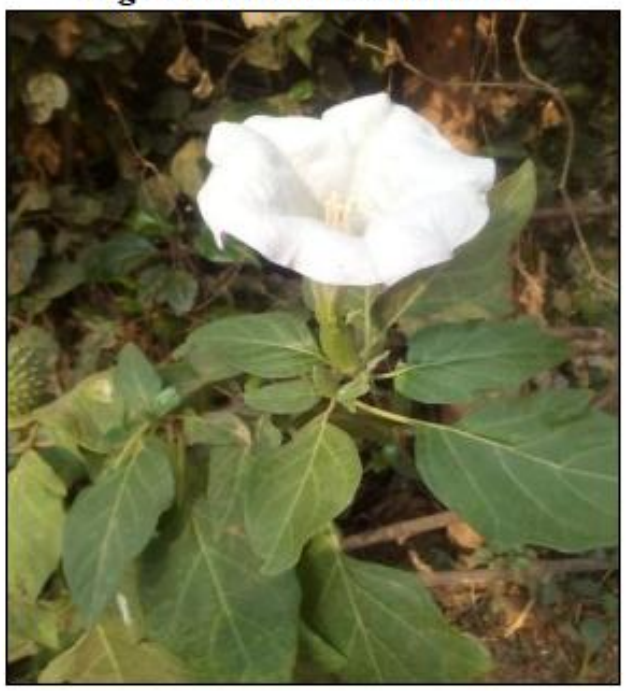

Fig. 3 Datura mete1 L.

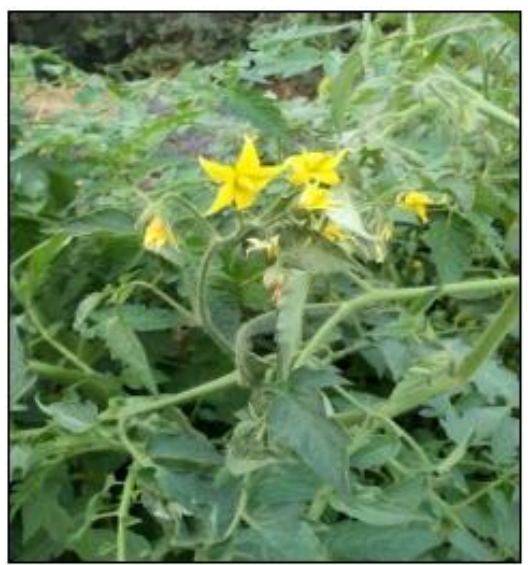

Fig. 4 Lycopersicon lycopersicum L.

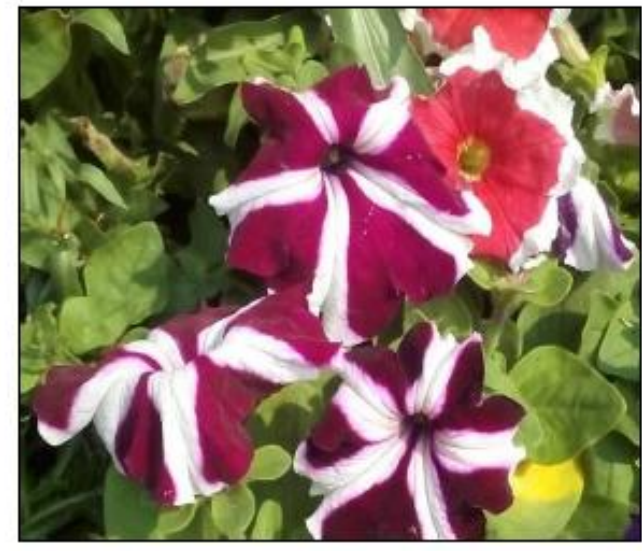

Fig. 5 Petunia Juss

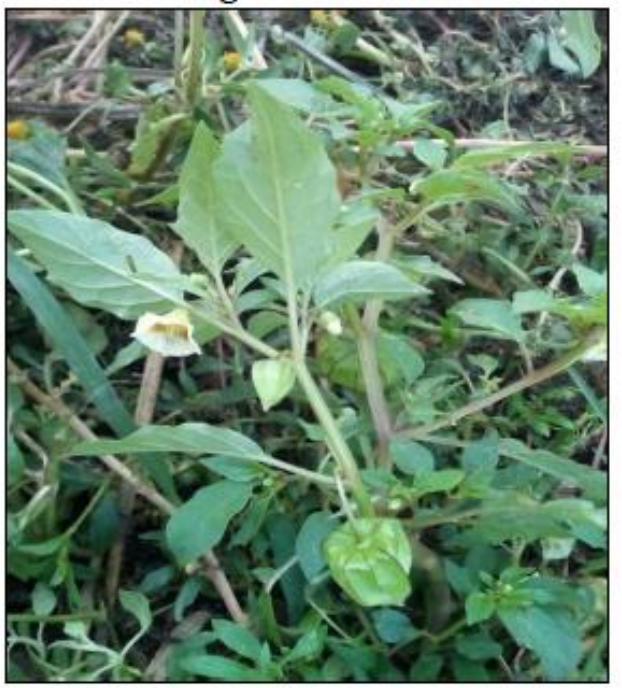

Fig. 6 Physalis minima L. 


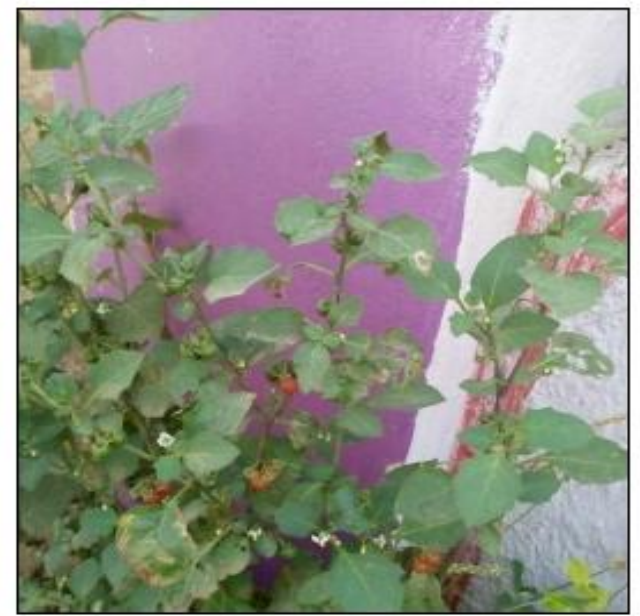

Fig. 7 Solanum denticulum $L$.

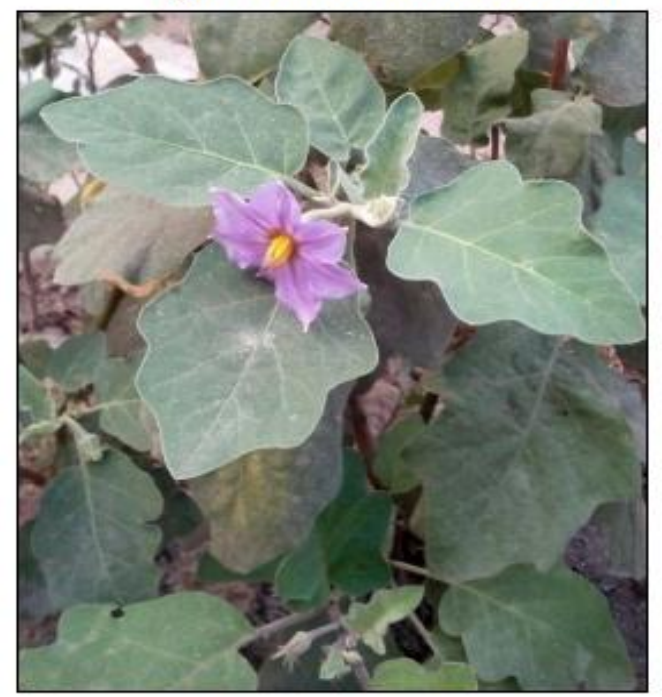

Fig. 8 Solanum melongena $L$.

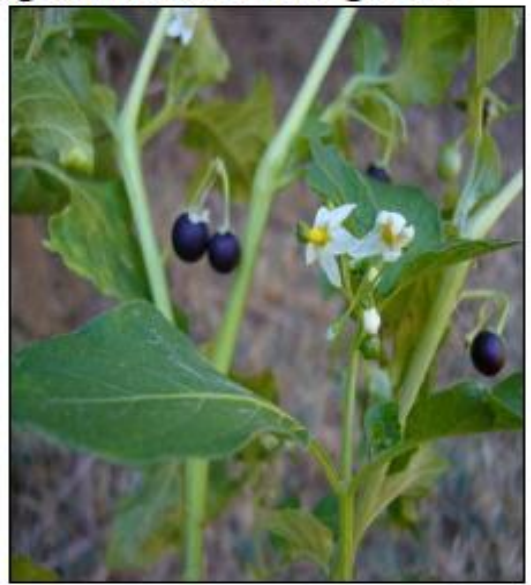

Fig. 9 Solanum nigrum $L$.

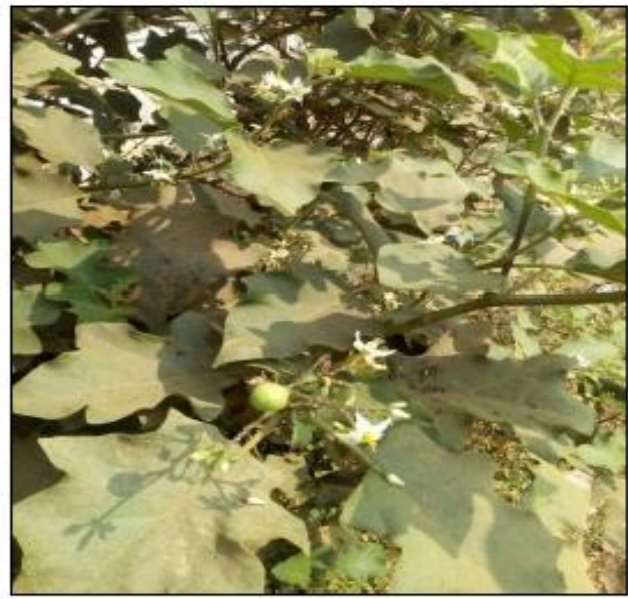

Fig. 10 Solanum tarvum S. W.

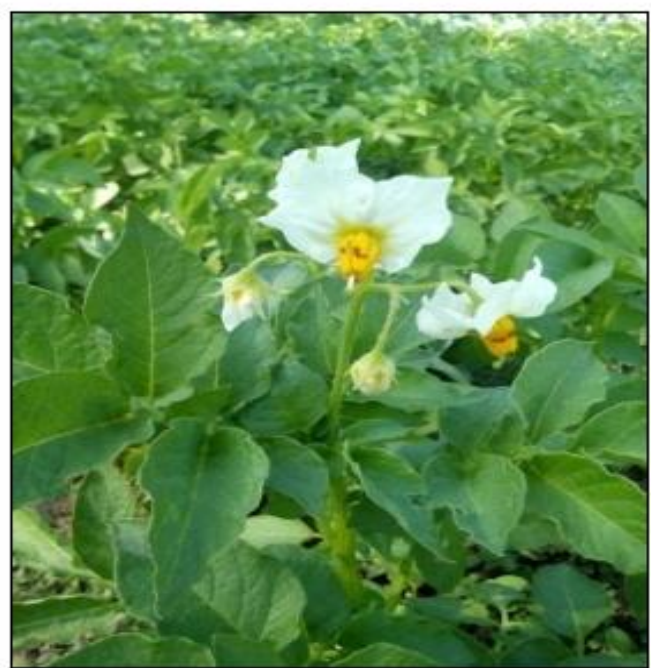

Fig. 11 Solanum tuberosum L.

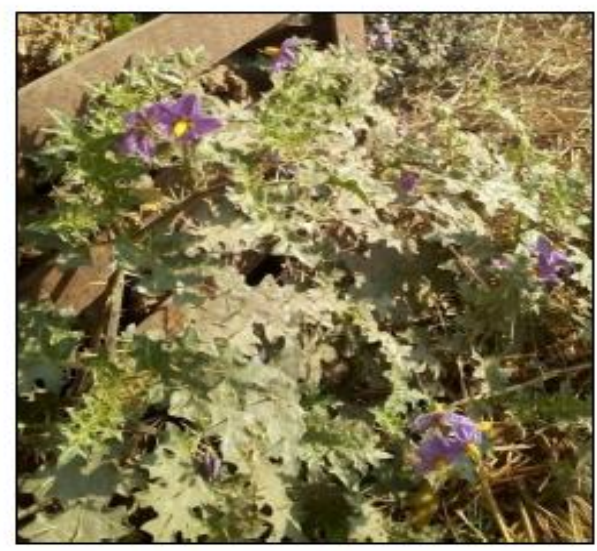

Fig. 12 Solanum virginianum $L$. 
I J R B A T, Issue (VIII), Vol. I, Jan 2020: 59-71

A Double Blind Peer Reviewed Journal
OPEN $\bigcirc$ ACCESS

e-ISSN 2347 - 517X

Original Article

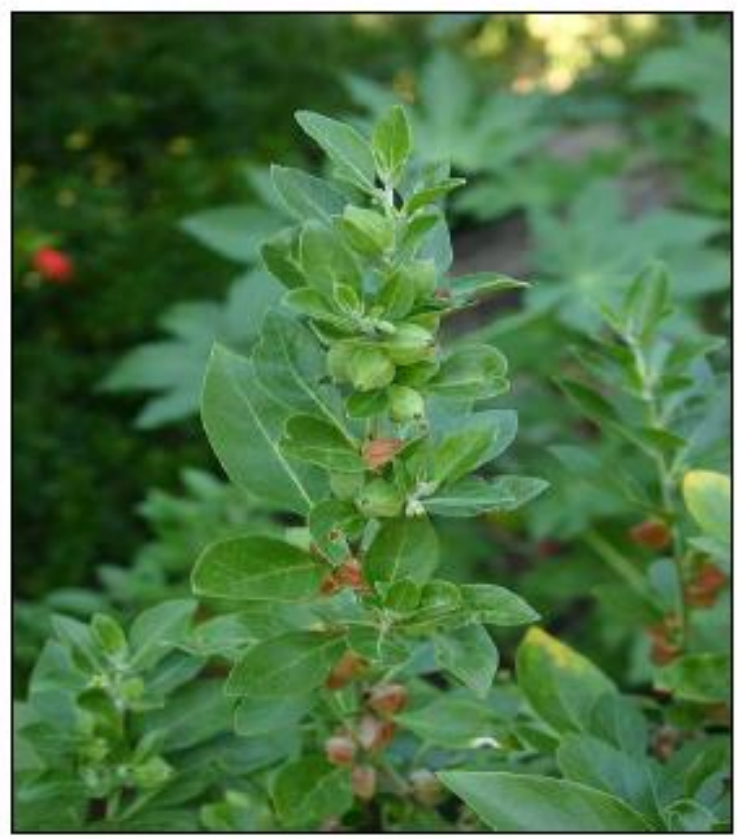

Fig. 13 Withania somnifera L. 